\title{
KEGIATAN SOSIALISASI TERPADU PKM EFEKTIVITAS IKLAN SEBAGAI UPAYA MENINGKATKAN BRAND IMAGE PADA SOTO MINANG RODA
}

\author{
Hilda Mary ${ }^{1)}$, Indriyenni' ${ }^{2)}$, Nila Pratiwi ${ }^{3)}$ \\ 1,2,3 Universitas Putra Indonesia YPTK Padang \\ email: hilda_mary@upiyptk.ac.id
}

Submit : 08/10/2021| Accept : 01/11/2021| Publish: 30/12/2021|

\begin{abstract}
Small and Medium Enterprises (SMEs) play a very important role for the Indonesian economy, including the economy of the city of Padang. Data from the Central Statistics Agency (BPS) shows that the percentage of the number of Small and Medium Enterprises (SMEs) compared to the total number of companies in 2010 was 99 percent, while the rest were large companies. In the same year the number of workers absorbed in this sector reached 97 percent of the total working workforce. Small and Medium Enterprises (SMEs) play a very important role for the Indonesian economy, including the economy of the city of Padang. Data from the Central Statistics Agency (BPS) shows that the percentage of the number of Small and Medium Enterprises (SMEs) compared to the total number of companies in 2010 was 99 percent, while the rest were large companies. In the same year the number of workers absorbed in this sector reached 97 percent of the total working force.
\end{abstract}

Keywords: Brand, Soto, Devotion

\begin{abstract}
Abstrak
Usaha Kecil dan Menengah (UKM) memegang peranan yang sangat penting bagi perekonomian Indonesia, termasuk di dalam nya adalah perekonomian Kota Padang. Data dari Badan Pusat Statistik (BPS) menunjukkan bahwa persentase jumlah Usaha Kecil dan Menengah (UKM) dibandingkan dengan total perusahaan pada tahun 2010 adalah sebanyak sebesar 99 persen, sedangkan sisanya adalah perusahaan besar. Pada tahun yang sama jumlah tenaga kerja yang terserap pada sector ini mencapai sebesar 97 persen dari total angkatan kerja yang bekerja.Usaha Kecil dan Menengah (UKM) memegang peranan yang sangat penting bagi perekonomian Indonesia, termasuk di dalam nya adalah perekonomian Kota Padang. Data dari Badan Pusat Statistik (BPS) menunjukkan bahwa persentase jumlah Usaha Kecil dan Menengah (UKM) dibandingkan dengan total perusahaan pada tahun 2010 adalah sebanyak sebesar 99 persen, sedangkan sisanya adalah perusahaan besar. Pada tahun yang sama jumlah tenaga kerja yang terserap pada sector ini mencapai sebesar 97 persen dari total angkatan kerja yang bekerja.
\end{abstract}

Kata Kunci: Brand, Soto, Pengabdian

\section{PENDAHULUAN}

Usaha Kecil dan Menengah (UKM) memegang peranan yang sangat penting bagi perekonomian Indonesia, termasuk di dalam nya adalah perekonomian Kota Padang. Data dari Badan Pusat Statistik (BPS) menunjukkan bahwa persentase jumlah Usaha Kecil dan Menengah (UKM) dibandingkan dengan total perusahaan pada tahun 2010 adalah sebanyak sebesar 99 persen, sedangkan sisanya adalah perusahaan besar. Pada tahun yang sama jumlah tenaga kerja yang terserap pada sector ini mencapai sebesar 97 persen dari total angkatan kerja yang bekerja. Sumbangan pada Produk Domestik Bruto (PDB) pada perekonomian Indonesia mencapai 56 persen dari total Produk Domestik Bruto (PDB), dengan nilai penciptaan devisa lebih dari 20 persen. Sepertihal nya kontribusi Usaha Kecil dan Menengah (UKM) secaranasional, Usaha 
Kecil dan Menengah (UKM) di Kota Padang juga memiliki peranan yang sangat penting bagi perekonomian Kota Padang, namun demikian perkembangan Usaha Kecil dan Menengah (UKM) di Kota Padang juga masih menghadapi berbagai permasalahan. Salah satu Usaha Kecil dan Menengah (UKM) di Kota Padang adalah Usaha Kecil dan Menengah (UKM) Soto Minag Roda yang juga masih menghadapi berbagai permasalahan. Berdasarkan kondisi tersebut maka pengembangan Usaha Kecil dan Menengah (UKM) di Kota Padang harus menjadi perhatian utama dalam pengembangan perekonomian.

Media sosial adalah media daring yang digunakan untuk kebutuhan komunikasi jarak jauh, proses interaksi antara user satu dengan user lain, serta mendapatkan sebuah informasi melalui perangkat aplikasi khusus menggunakan jaringan internet. Tujuan dari adanya social media sendiri adalah sebagai sarana komunikasi untuk menghubungkan antar pengguna dengan cakupan wilayah yang sangat luas.

Agar pengguna media sosial (medsos) lebih mudah dan cepat, dibutuhkan koneksi internet yang stabil dan cepat. Kita tidak perlu lagi menghubungi orang lain melalui kabel telepon atau alat komunikasi tradisional. Cukup dengan mengakses media sosial, kita dapat terhubung dengan banyak orang, membuat forum, diskusi bersama, mengunggah aktivitas keseharian, dan juga mengenalkan produk dari makanan.

Apa yang Kita bisa definisikan ketika mengetahui kata Sosial Media Marketing? Sederhananya sosial media marketing adalah sebuah iklan yang dipromosikan menggunakan sosial media. Iklan jenis ini banyak yang bilang lebih efisien dibandingkan dengan iklan-iklan konvensional. Kebanyakan iklan sosial media dilakukan di platform seperti Facebook, Twitter, hingga Instagram.
Menurut data dari We Are Social sebanyak 170 juta orang di Indonesia sudah menggunakan Sosial Media.

Melihat dari data tersebut bisa disimpulkan bahwa beriklan sosial media sangat menguntungkan. Jumlah pengguna instagram dapat menjadi pelanggan potensial yang menjanjikan. Kelebihan lainnya adalah kemudahan perusahaan untuk menjangkau target market mereka. Ditambah lagi proses yang beriklan di sosial media sangatlah gampang dan menyenangkan. Dulu sebelum hadirnya iklan sosial media. Untuk melakukan promosi di internet perusahaan hanya bisa melakukannya dengan website, kekurangan menggunakan website ini adalah tidak ada komunikasi yang interaktif antara penjual dan pembeli. Namun, jika menggunakan sosial media komunikasi tersebut bisa dilakukan secara dua arah.

\section{METODE KEGIATAN}

Berdasarkan rumusan masalah yang telah dijelaskan diatas,maka tujuan yang ingin dicapai dalam PKM ini untuk mengetahui dan meningkatkan, Meningkatkan pendapatan usaha Soto Minang Roda. Dapat memberikan inovasi dalam pengenalan produk melalui efektivitas iklan pada Soto Minang Roda. Untuk meningkatkkan pengetahuan tentang manajemen pemasaran yang berbasis teknologi. Lokasi tempat pelaksanaan PKM ber alamat di Jl. S. Parman No.136 C, Lolong Belanti, Kec. Padang Utara, Kota Padang, Sumatera Barat.

\section{HASIL DAN PEMBAHASAN}

Hampir semua pengguna internet di Indonesia menggunakan WhatsApp. Mungkin Kita salah satunya. Ada sekitar 124 juta pengguna internet menggunakan WhatsApp di gadget mereka. Penggunanya pun beragam, mulai dari usia 16 tahun hingga 64 tahun. Mereka biasanya menggunakan WhatsApp untuk 
berkomunikasi dengan keluarga dan teman. Fitur-fitur yang mudah digunakan seperti chat, panggilan suara, dan video jadi favoritnya.

Tak hanya untuk komunikasi antar kerabat dan kolega, kini pemilik bisnis juga bisa memanfaatkannya untuk bisnis mereka. WhatsApp telah meluncurkan platform khusus bisnis, yaitu WhatsApp Bisnis. Berbeda dengan WhatsApp yang biasa digunakan banyak orang, WhatsApp Bisnis punya fitur khusus yang dapat menunjang kebutuhan komunikasi dan pemasaran pemilik bisnis. Ketika Kita melakukan digital marketing, baik itu di platform media sosial ataupun internet secara luas, tentu Kita harus memberikan visual terbaik agar mampu menarik perhatian calon pelanggan. Selain itu, membuat gambar dan video yang menarik tentunya bisa merepresentasikan produk maupun jasa yang ditawarkan.

Untuk Kita yang memiliki budget cukup, Kita bisa mempercayakan produksi gambar maupun video marketing ini pada salah satu tim digital marketing agency Indonesia yang sudah berpengalaman dan memiliki tim desain creative marketing dan social media marketing. Namun, untuk Kita yang masih berada dalam tahapan digital marketing for small business atau pemasaran digital untuk UMKM dan UKM dengan anggaran yang masih terbatas, maka Kita bisa mencoba memproduksi gambar dan video sendiri.

\section{Perhatikan Letak Sumber Cahaya}

Tidak mau tangkapan gambar yang Kita hasilkan terlihat buram, penuh noise, kurang tajam, bukan? Oleh karena itu, hal pertama yang harus Kita perhatikan adalah pencahayaan saat proses pemotretan. Kita harus menyesuaikan dengan arah cahaya. Apakah dari samping, depan, ataukah dari belakang. Misalnya saja, saat pengambilan gambar di luar ruangan, pastikan objek tidak membelakangi cahaya, terutama untuk pembuatan video atau gambar bergerak. Aturan ini juga berlaku pada sumber cahaya lain di luar cahaya alami (matahari) atau disebut juga cahaya buatan.

\section{Pastikan Kamera Kokoh, Tidak Goyang}

Selain pencahayaan, pastikan kamera yang Kita gunakan tidak goyang saat proses pengambilan gambar dalam produksi video dimulai. Sebab, hal ini dapat mengurangi kualitas gambar maupun video yang dihasilkan. Untuk menghindari tremor pada tangan ketika memegang kamera, Kita bisa menggunakan bantuan tripod atau monopod dalam menopang kamera agar tetap kokoh. Selain itu, jika memungkinkan, tambahkan penggunaan gimbal atau stabilizer untuk hasil yang lebih maksimal atau tidak goyang.

\section{Pastikan Titik Fokus pada Objek}

Pada kamera, baik itu kamera profesional berupa kamera digital, SLR, mirrorless ataupun penggunaan kamera smartphone, semuanya memiliki titik fokus yang bisa Kita tempatkan sesuai dengan keinginan, namun terkadang dilupakan. Hal inilah yang umumnya memicu gambar yang dihasilkan menjadi blur atau tidak fokus.

Sebelum melakukan pembuatan video untuk promosi, pastikan lensa Kita sudah fokus pada objek. Baru setelah, Kita menekan tombol shutter. Ini bisa menghindarkan Kita agar jangan sampai menghasilkan gambar maupun video yang tidak fokus, dan berakibat proses pembuatan video atau take foto diulang lagi.

\section{Tidak Terlalu Sering Melakukan Zoom}

Dalam proses pengambilan gambar, sebaiknya Kita tidak terlalu banyak melakukan zoom, kecuali jika memang dibutuhkan sebagai variasi. Mengapa begitu? Karena bagaimanapun, kualitas gambar normal dan kualitas gambar yang 
dihasilkan menggunakan fitur zoom akan sedikit berbeda. Apalagi jika diterapkan saat pemotretan atau pengambilan video bergerak untuk produk tertentu.

Dibandingkan melakukan fitur memperbesar gambar, jauh lebih baik jika kamera yang mendekat pada objeknya. Terkecuali untuk momen tertentu yang memang membutuhkan efek video dramatis, seperti fokus pada ekspresi wajah yang lucu, atau zoom video yang sengaja dibuat untuk menghibur.

\section{Kondisikan Lingkungan Sekitar}

Proses pengambilan gambar maupun video di luar ruangan, maupun di dalam ruangan atau studio tentu memiliki tantangannya tersendiri. Apalagi jika Kita memilih lokasi yang ramai pengunjung seperti taman atau cafe. Kita dan tim harus memastikan tidak ada orang yang melintas secara tiba-tiba, baik itu di depan objek, ataupun tepat di depan kamera saat proses pengambilan gambar berlangsung.

Selain itu, dalam produksi gambar bergerak atau video, sebaiknya Kita memperhatikan durasi. Jangan membuat video yang terlalu lama dan terkesan monoton. Sebaliknya, jangan pula merekam dalam durasi yang terlalu pendek.

Jadi, rekamlah secukupnya. Jika perlu, lakukan beberapa pengambilan gambar random, namun tetap sesuai pada konsep yang sebelumnya Kita susun menggunakan storyboard. Gambar random bisa membantu Kita untuk improvisasi saat proses editing.

\section{Pastikan Suara Jernih}

Jika Kita melakukan pengambilan gambar, terutama video di luar ruangan, tentunya akan ada suara-suara yang tak diharapkan ikut terekam. Misalnya seperti suara angin, lalu lalang kendaraan, suara orang bercakap-cakap, dan lain sebagainya. Oleh sebab itu, Kita memerlukan tool atau alat untuk mengurangi gangguan kebisingan tersebut.

Ya, Kita dapat menambahkan alat seperti wind muffler pada kamera untuk meredam suara-suara yang tidak diperlukan. Selain itu, untuk merekam hasil wawancara narasumber ataupun bincangbincang seputar produk atau jasa yang Kita tawarkan, Kita dapat menggunakan mikrofon kecil eksternal, agar suara yang dihasilkan terdengar jelas atau jernih.

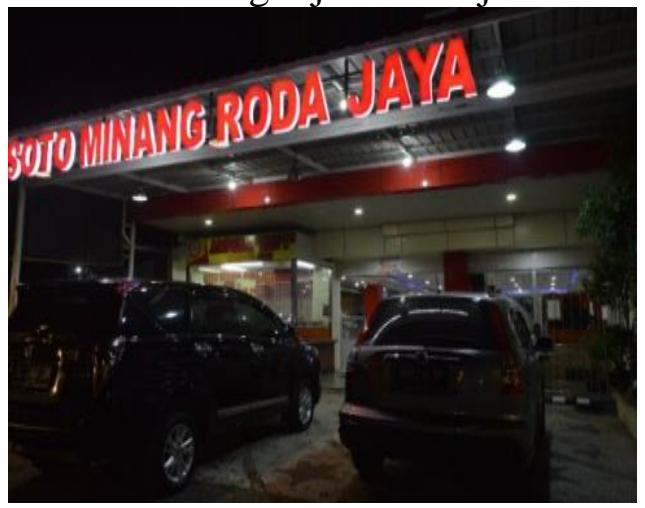

Gambar 1. Objek Penelitian

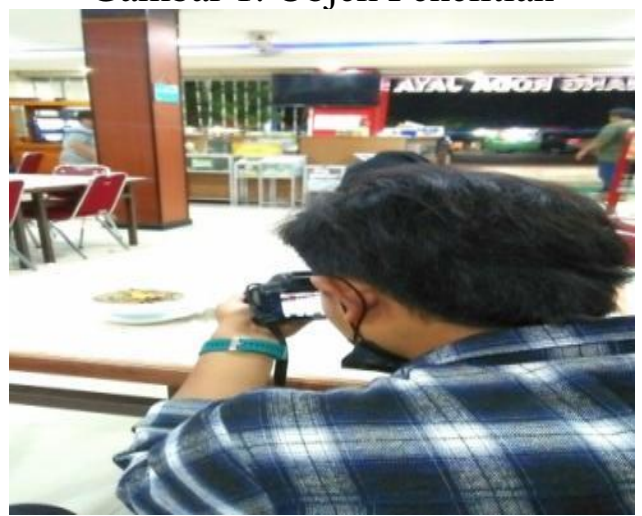

Gambar 2. Proses Pengerjaan

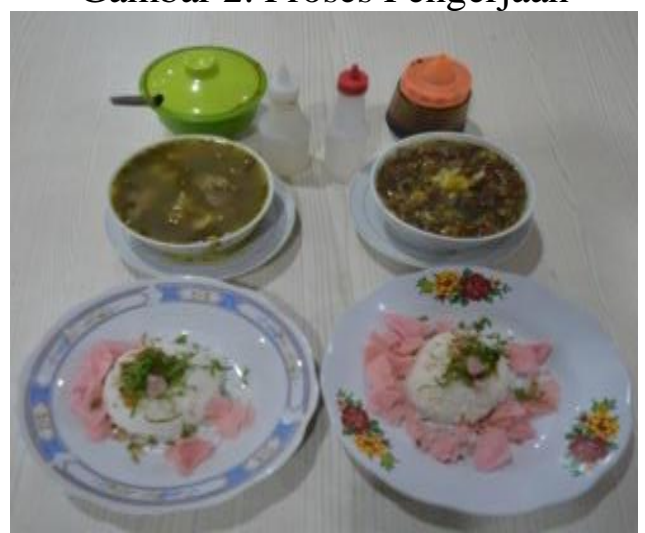

Gambar 3. Foto Produk 

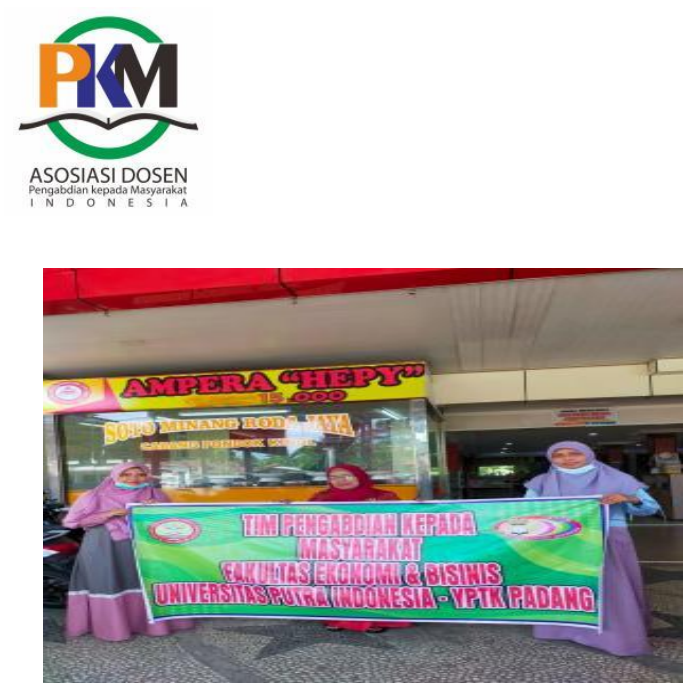

Gambar 4. Bukti Pelaksanaan

\section{SIMPULAN}

Berdasarkan PKM yang sudah dilaksanakan dapat disimpulkan bahwa Soto Minang Roda Agar dapat lebih berkembang dengan lebih memanfaatkan sosial media dan perlu nya instagram yang aktif untuk selalu meng upload foto atau video yang bertema tentang makanan yang disediakan, ini dapat lebih diminati oleh masyarakat, dapat berkembang maju dengan baik dan dapat terus mempertahankan eksistensinya.

\section{DAFTAR PUSTAKA}

Basuki, N., \& Sangadji, S. S. (2020). Pengelolaan Kelapa Terpadu Zero Waste Di Desa Lembah Asri Kecamatan Weda Selatan. Jurnal Abdimas Bina Bangsa, 1(2), 231239.

Khayroiyah, S. (2020, October). Sosialisasi Penggunaan Media Pembelajaran Kokodas Di Sd Swasta Islam Terpadu Uli Arga Patumbak. In Prosiding Seminar Nasional Hasil Pengabdian (Vol. 3, No. 1, pp. 281287).

Nuraida, N., Mandasari, M., Baihaqi, B., Hakim, S., \& Akmal, A. (2019). Sosialisasi Penyediaan Pangan Sehat Pada Kegiatan Posbindu Ptm Di Desa Blang Reuling Kecamatan Kota Juang Kabupaten Bireuen. Rambideun: Jurnal Pengabdian Kepada Masyarakat, 2(2), 7-10.
Jurmas Sains dan Teknologi eISSN: 2775-7013

Vol. 2 No. 4

Hal: 16-21

Doi: https://doi.org/10.47841/saintek.v2i4.53

Puspita, R. D., \& Wardani, D. S. (2021). Pelatihan Perangkat Pembelajaran Tematik Terpadu Berbasis Model Interactive-Compensatory Untuk Guru-Guru Sekolah Dasar Negeri Cingcin 1 Kecamatan Soreang Kabupaten Bandung. Abdimas Siliwangi, 4(2), 167-178.

Sundari, M., Megawati, A., Agusti, L. S., \& Ningsih, R. (2021). PKM Kelompok Pendidikan di Paud Islam Terpadu Al-Barkah Jakarta Timur. ARSY: Jurnal Aplikasi Riset kepada Masyarakat, 2(1), 102-105.

Sari, D. N., \& Putri, S. O. (2020, September). Pkm Media Pembelajaran Camat Bermuatan Karakter Untuk Meningkatkan Kualitas Pembelajaran Guru Sd Swasta Islam Terpadu Uli Arga Desa Sigara-Gara Kecamatan Patumbak Kabupaten Deli Serdang Provinsi Sumatera Utara. In Prosiding Seminar Nasional Hasil Pengabdian (Vol. 3, No. 1, pp. 101106).

Siregar, T. J., \& Khayroiyah, S. (2019, February). Sosialisasi Penggunaan Media Pembelajaran Grafis Untuk Meningkatkan Kualitas Pembelajaran Guru Sd Swasta Islam Terpadu Uli Arga Patumbak. In Prosiding Seminar Nasional Hasil Pengabdian (Vol. 2, No. 1, pp. 583588).

Siregar, T. J., \& Khayroiyah, S. (2019, February). Sosialisasi Penggunaan Media Pembelajaran Grafis Untuk Meningkatkan Kualitas Pembelajaran Guru Sd Swasta Islam Terpadu Uli Arga Patumbak. In Prosiding Seminar Nasional Hasil Pengabdian (Vol. 2, No. 1, pp. 583588). 
Umam, B. A. (2021). Upaya Peningkatan Pembelajaran E-Learning Terpadu Untuk Guru Smk Nahdlatun Nasyiin Kadur Pamekasan. JMM-Jurnal Masyarakat Merdeka, 3(2).

Wahyuningsih, S. \& Hidayati, N. R. (2019, December). Pkm Pkk Rw 08 Kelurahan Banjarejo Madiun Pengolahan Sampah Berkonsep Bank Sampah Menuju Lingkungan Berbasis Green And Clean. In Prosiding Seminar Nasional SIMBIOSIS (Vol. 4). 